\title{
STRATEGI PEMBELAJARAN GURU DALAM MEMENUHI KEBUTUHAN BELAJAR PESERTA DIDIK DITENGAH PANDEMI COVID-19 DI SD NEGERI 66 GANTARANG KABUPATEN SINJAI
}

\author{
Muhammad Aqsa ${ }^{1}$, Miftakul Khoiri \\ UIN Sunan Ampel Surabaya ${ }^{1,2}$
}

email: aqsa3777anakgunung@gmail.com,miftakulkhoiri123@gmail.com

\begin{abstract}
Currently, the world is faced with problems that affect all sectors including education with the covid-19 outbreak. So the teacher has extra work so that the educational process runs optimally by using several teaching methods that are by current conditions. The purpose of this study is to analyze the extent to which the efforts or roles of teachers in meeting the learning needs of students. In the learning process that is carried out outside the classroom, it is intended that all the needs of students, such as academic, psychological, and comfortable needs can be met. The method in this study used a data-based qualitative descriptive method. The author analyzes the needs of students in the learning process amid the Covid-19 pandemic and the learning strategies used by teachers in meeting the learning needs of students. Researchers analyzed how the strategies used by teachers at SD Negeri 66 Gantarang in meeting the learning needs of participants so that the learning needs of students could be met.
\end{abstract}

Keywords: Strategy, Needs, and Students

Perubahan zaman telah mengakibatkan pergeseran model pendidikan kearah yang lebih modern, ilmu pengetahuan dan teknologi menjadi kebutuhan dunia pendidikan saat ini, utamanya teknologi informasi memberikan pengaruh yang sangat besar terhadap perancangan dan penyusunan serta pengaplikasian suatu strategi pembelajaran dilembaga pendidikan saat ini. Kemajuan yang terjadi saat ini memungkinkan para pendidik untuk memanfaatkan berbagai media untuk pembelajaran yang sesuai dengan kebutuhan serta tujuan dari pembelajaran yang akan dicapai. Pemanfaatan media komunikasi saat ini dapat mempermudah proses pembelajaran, membuat pembelajaran lebih menarik dan disukai oleh peserta didik saat ini yang sudah terbiasa dengan penggunaan teknologi di lingkungannya.

Perubahan zaman telah mengakibatkan pergeseran model pendidikan kearah yang lebih modern, ilmu pengetahuan dan teknologi menjadi kebutuhan dunia pendidikan saat ini, utamanya teknologi informasi memberikan pengaruh yang sangat besar terhadap perancangan dan penyusunan serta pengaplikasian suatu strategi pembelajaran dilembaga pendidikan saat ini. Kemajuan yang terjadi saat ini memungkinkan para pendidik untuk memanfaatkan berbagai media untuk pembelajaran yang sesuai dengan kebutuhan serta tujuan dari pembelajaran yang 
akan dicapai. Pemanfaatan media komunikasi saat ini dapat mempermudah proses pembelajaran, membuat pembelajaran lebih menarik dan disukai oleh peserta didik saat ini yang sudah terbiasa dengan penggunaan teknologi dilingkungannya. Ditengah kemajuan dunia pendidikan, saat ini bangsa Indonesia dan negaranegara lainnya didunia ini tengah dihadapkan pada persoalan merebaknya virus covid-19 yang mempengaruhi hampir segala sektor. Permasalahan ini menimbulkan persoalan baru khususnya dalam sistem pendidikan yaitu dengan adanya libur sekolah secara nasional yang telah berlangsung beberapa bulan. Sehingga proses pendidikan disekolah menjadi terkendala untuk dilakukan, sementara para peserta didik masih sangat membutuhkan proses pendidikannya. Hal ini yang kemudian menimbulkan permasalahan dalam dunia pendidikan, sehingga para guru dan orang tua peserta didik memiliki tanggung jawab yang lebih besar ditengah pandemi covid-19 untuk tetap melaksanakan tugas dan tanggung jawabnya dalam memenuhi kebutuhan belajar peserta didik.

Pembelajaran merupakan suatu proses pemberian bantuan yang dilakukan oleh seorang guru terhadap peserta didik agar terjadi suatu proses perolehan ilmu dan pengetahuan, penguasaan, kemahiran, dan tabiat serta pembentukan sikap dan keyakinan oleh peserta didik. Dengan kata lain pembelajaran adalah suatu proses yang akan membantu peserta didik sehingga memiliki kemampuan belajar yang baik.(Susanto, 2013, hlm. 13)

Mengajar bukan hanya profesi yang paling ditinjau dari kesejahteraan manusia, akan tetapi juga profesi, yang paling teknis dan sulit. Kerja guru bukan hanya sekedar memberi tugas dan memeriksa apakah anak menghafalnya. Guru adalah pembangun, pembentuk, kehidupan yang diberi kepercayaan bangsa dan ummat manusia, dalam membangun masa depan yang lebih bahagia. Seperti halnya dengan profesi lain, juga guru harus melalui persiapan yang lama dan ketat. Sukar memperkirakan banyaknya hidup manusia yang terbuang sia-sia, banyaknya kejahatan, kekecewaan, dan penderitaan karena pendidikan yang salah.(Nurdin, Syafruddin, 2016, hlm. 9-10)

Upaya dalam peningkatan skill dan pengetahuan peserta didik ada pada proses pembelajaran yang dilakukan disekolah. Kebanyakan peserta didik 
menganggap bahwa sekolah adalah tempat yang sangat menyenagkan, karena banyak teman bermain. Karena pada dasarnya sekolah menjadi tempat berinteraksi para peserta didik dengan teman dan guru. Akan tetapi hal itu menjadi sulit saat ini dengan adanya covid-19.(Syah, 2020)

Dalam proses pembelajaran di SD Negeri 66 Gantarang ditengah pandemi covid-19 ini, para guru memiliki cara tersendiri guna memenuhi kebutuhan belajar peserta didik saat ini. Strategi yang digunakan juga beragam seperti pembelajaran online, pembelajaran dari rumah kerumah, dan proses pembelajaran jarak jauh dengan kerja sama antara guru dan orang tua peserta didik.

Pada pelaksanaan proses pendidikan di sekolah, para pengajar mengakui bahwa penggunaan buku sebagai bahan pelajaran yang dijadikan acuan dalam membina peserta didik. Hal ini menyebabkan terjadinya beberapa kendala yang dihadapi oleh peserta didik, disebabkan karena proses pembelajaran lebih banyak menggunakan pendengaran dan mencatat materi yang disampaikan guru sehingga proses pembelajaran tidak dapat berjalan maksimal.(Rohani, Ahmad, 1995, hlm. 36) Oleh karena itu dengan adanya kebijakan pemerintah dengan penerapan pembelajaran jarak jauh, maka guru tetap menjadi pembimbing peserta didik dengan tetap mengikuti sistematika pembelajaran umum dengan menggunakan strategi pembelajaran yang berbeda-beda sesuai dengan tingkatan kelas peserta didik yang akan diberi pelajaran. Tentunya dengan tetap memperhatikan faktor penunjang lainnya seperti kegembiraan belajar peserta didik yang dapat digunakan oleh para guru didalam meningkatkan hasil pencapaian belajar peserta didik ditengah pandemic covid-19. Seperti kata Ki Hadjar Dewantara yang memberi anjuran kepada unsur pendidikan agar harus menciptakan suasan gembira.(Pendidikan yang Menggugah dan Menggairahkan di Tengah Covid-19, t.t.)

Pemenuhan kebutuhan belajar peserta didik menjadi langkah tepat yang harus segera dilakukan, sehingga kreatifitas para tenaga pendidik ditengah pandemi covid-19 sangat dibutuhkan, para pendidik tidak boleh berpangku tangan menunggu kebijakan langkah apa yang harus diikuti, tetapi para pendidik seharusnya mampu memberikan suatu solusi tepat yang sejalan dengan aturan- 
aturan yang ada sehingga proses pendidikan tetap dapat berjalan optimal ditengah pandemi covid-19 saat ini.

\section{Metode}

Metode penulisan yang digunakan pada penulisan ini adalah metode deskriptif kualitatif berbasis data. Penulis melakukan analisis terhadap kebutuhankebutuhan peserta didik dalam proses pembelajaran ditengah pandemi covid-19. Adapun pengertian dari penelitian deskriptif adalah suatu proses penelitian yang yang bertujuan untuk mengklarifikasi sebuah permasalahan yang terjadi dengan melakukan deskripsi terkait dengan masalah yang diteliti. Penelitian kualitatif merupakan suatu tindakan penelitian yang terfokus terhadap quality dari suatu masalah. Seperti gejala sosial, fenomena yang terjadi yang kemudian dijadikan bahan berpikir dalam melakukan pengembangan suatu teori.(Djunaidi, M, 2012, hlm. 25)

Melihat teori diatas dapat disimpulkan bahwa penelitian yang dilakukan ini untuk mengeksplorasi kejadian sosial khususnya dalam proses pendidikan terfokus proses belajar mengajar dirumah ditengah vademi covid-19. Penelitian ini dapat dijadikan sebagai acuan untuk mengembangkan teori-teori, memberikan beberapa tawaran kepada para pemangku kebijakan khususnya kebijakan pendidikan. Penelitian ini melihat data-data dari lapangan, yang kemudian dilakukan analisis lebih dalam terkait dengan kebutuhan peserta didik, yang diharapkan mampu memberikan solusi dalam memecahkan persoalan yang terkait dengan kebutuhan-kebutuhan peserta didik selama proses pembelajaran dirumah ditengah pandemi covid-19.

\section{Pembahasan}

\section{Pengertian Strategi Pembelajaran}

Strategi didalam dunia pendidikan diartikan sebagai a pland method, or series of activities designed to achieves a particular educational. Strategi pembelajaran dapat diartikan sebagai perencanaan yang didalamnya terdapat rangkaian kegiatan yang didesain guna mencapai tujuan pendidikan yang 
diharapkan.(Sanjaya, 2006, hlm. 126) Selain itu Strategi pembelajaran merupakan cara-cara yang berbeda untuk mencapai hasil pembelajaran yang berbeda di bawah kondisi yang.(Wena, 2008, hlm. 5)

\section{Kebutuhan Peserta Didik}

Dalam Undang-undang RI Nomor 20 Tahun 2003 pada pasal 1 ayat 4 disebutkan bahwa peserta didik adalah anggota masyarakat yang berusaha mengembangkan potensi diri melalui proses pembelajaran yang tersedia pada jalur, jenjang, dan jenis pendidikan tertentu. Kemudian, pada pasal 6 ayat 1 disebutkan setiap warga Negara yang berusia tujuh tahun sampai dengan lima belas tahun wajib mengikuti pendidikan dasar (SD dan SMP).(Wiyani, 2013, hlm. 130)

Adapun hak-hak peserta didik sesuai dengan pasal 12 adalah sebagai berikut:

1. Mendapatkan pendidikan agama sesuai dengan agama yang dianutnya dan diajarkan oleh pendidik yang seagama.

2. Mendapatkan pelayanan pendidikan sesuai dengan bakat, minat dan kemampuannya.

3. Mendapatkan beapeserta didik bagi yang berprestasi yang orang tuanya tidak mampu membiayai pendidikan.

4. Mendapatkan biaya pendidikan bagi mereka yang orang tuanya tidak mampu membiayai pendidikannya.

5. Pindah keprogram pendidikan pada jalur dan satuan pendidikan lain yang setara.

6. Menyelesaikan program pendidikan sesuai dengan kecepatan belajar masingmasing dan tidak menyimpang dari ketentuan batas waktu yang diterapkan.(Wiyani, 2013, hlm. 130)

Itulah penjelasan singkat terkait hak-hak peserta didik yang diatur dalam Undang-undang secara umum. Yang kemudian menjadi acuan sistem pendidikan saat ini. Oleh sebab itu dianggap penting untuk menganalisis kebutuhan peserta didik dalam proses pembelajaran dikelas. Sebagaimana diketahui bersama bahwa 
peserta didik menempati posisi yang sangat sentral dalam proses pembelajaran, khususnya dalam dunia pendidikan.

Smaldino, Lowther dan Russell dalam menganalisis peserta didik dengan mengajukan tiga faktor kunci untuk menentukan keberhasilan yang mencakup karakteristik umum (general characteristics), kemampuan awal khusus (specific entry competencies) dan gaya belajar (learning styles). Penulis memisahkan gaya belajar dengan kecerdasan jamak sehingga menambahkan satu faktor kunci lainnya, yaitu kecerdasan jamak (multiple intellegences). Karakteristik umum meliputi gambaran tentang umur, jenis kelamin, (gender), tingkat, dan faktorfaktor budaya sosial ekonomi. Kemampuan awal khusus merujuk pada pengetahuan dan keterampilan yang dimiliki atau belum dimiliki peserta didik, seperti pengetahuan prasyarat, kemampuan yang ditargetkan, dan sikap. Adapun gaya belajar merujuk pada ciri-ciri psikologis yang memengaruhi bagaimana pandangan dan respon peserta didik pada stimulus yang diberikan. Ciri psikologis yang dimaksud adalah kekuatan dan kesukaan memberi pesepsi, kebiasaan memproses informasi, motivasi, dan berbagai aspek psikologis lainnya.(Yaumi, 2013, hlm. 122)

Guru dan tenaga kependidikan harus memiliki tekhnik dalam mengidentifikasi kebutuhan peserta didik dalam belajar, identifikasi harus dilakukan diawal proses pembelajaran sehingga hambatan yang dialami peserta didik dapat diatasi. Tujuannya agar dapat diketahui keinginan dan harapan peserta didik terhadap bahanajar yang akan diberikan, hal ini dianggap penting agar dalam proses pembelajaran terdapat aturan yang akan dilaksanakan.(Hsubky, 2014, hlm. 54) Melalui pembelajaran yang dilakukan oleh para guru dapat memenuhi kebutuhan belajar peserta didik, proses ini dapat menjadi sangat bermakna bagi peserta didik. Hal ini karena pelajaran yang diberikan oleh guru data digunakna oleh peserta didik didalam kehidupan mereka sehingga peserta didik merasa nyaman dalam belajar.(Bagaimana Pembelajaran yang Sesuai Kebutuhan Siswa, t.t.) 
Selain itu faktor lain yang perlu diperhatikan adalah kebutuhan akademik peserta didik, berikut beberapa kebutuhan akademik peserta didik:(Jones, Vern, 2012, hlm. 242)

1. Paham dan nilai tujuan belajar

2. Paham proses belajar

3. Terlibat secara aktif dalam proses belajar

4. Mempunyai tujuan belajar yang berkaitan dengan minat dan pilihan mereka sendiri.

5. Menerima intruksi yang sesuai dengan gaya belajar dan kekuatan mereka

6. Melihat belajar yang dimodelkan oleh orang dewasa sebagai proses yang menarik dan mempunyai imbalan

7. Pengalaman berhasil

8. Mempunyai waktu untuk mengintegrasikan pembelajaran

9. Menerima umpan balik yang realistis dan langsung yang meningkatkan perasaan menguasai materi self-efficacy

10. Terlibat dalam evaluasi diri atas pembelajaran dan upaya mereka

11. Menerima imbalan yang sesuai untuk mendapatkan keberhasilan

12. Merasakan lingkungan belajar yang mendukung, aman dan terorganisasi dengan baik.

Analisis kebutuhan akademik peserta didik sangat membantu guru dalam proses pembelajaran yang bertujuan untuk mencapai tujuan pendidikan yang telah dirancang, oleh sebab itu peran guru sangat penting dalam proses pembelajaran. Suatu organisasi yang disebut search institute mengembangkan daftar 40 aset yang membantu peserta didik dalam mengembangkan potensi mereka. Namun dalam penelitian ini penulis hanya akan menuliskan faktor defisitnya. Organisasi ini juga mendaftar 5 yang menyebabkan defisit perkembangan, yakni, pesta alcohol, kesepian dirumah, menjadi korban kejahatan, terlalu banyak menonton televise dan kekerasan fisik. Sayangnya pada penelitian ini, ditemukan bahwa hanya $15 \%$ remaja yang disurvei yang tidak mengalami difisit ini. Sepertiga (32\%) mengalami tiga atau lebih.(Jones, Vern, 2012, hlm. 9) 
Selain faktor-faktor diatas, berikut faktor lain yang dapat menyebabkan terjadinya perilaku menyimpang bagi peserta didik. Pertama, longgarnya pegangan terhadap agama. Sudah menjadi tragedy dan dunia maju, dimana segala sesuatu hampir dapat dicapai dengan ilmu pengetahuan, sehingga keyakinan beragama mulai terdesak, kepercayaan kepada Tuhan tinggal simbol, laranganlarangan dan perintah Tuhan tidak diindahkan lagi. Kedua, kurang efektifnya pembinaan moral yang dilakukan oleh rumah tangga, sekolah, maupun masyarakat. Ketiga, derasnya arus budaya materialistis, hedonistis, sekularistik. Keempat, belum adanya kemauan sungguh-sungguh dari pemerintah. Pemerintah diketahui memiliki kekuasaan (power), uang, teknologi, sumber daya manusia, dan sebagainya tampaknya belum menunjukkan kemauan yang sungguh-sungguh untuk melakukan pembinaan moral bangsa.(Nata, 2003, hlm. 206)

Permasalahan-permasalahan diatas merupakan permasalahan yang masih sering terjadi ditengah lingkungan peserta didik, akan tetapi kadang tidak dinampakkan oleh peserta didik. Oleh sebab itu pendekatan guru terhadap peserta didik dapat membantu guru dalam memecahkan persoalan yang dihadapi oleh peserta didik. Karena permasalahan diatas cenderung terjadi kepada pribadi peserta didik yang didapatkannya diluar ligkungan sekolah. Sehingga agak sulit untuk mendeteksi permasalahan-permasalahan tersebut. Persoalan ini harus mampu diselesaikan oleh para guru dan ini merupakan tanggung jawab guru yang harus dilaksanakan selain bertugas mengajari peserta didik didalam ruang kelas.

Secara umum faktor yang dapat menyebabkan kesulitan belajar peserta didik dapat dibagi kedalam dua bagian, yaitu:(Arifin, 2013, hlm. 306)

1. Faktor internal peserta didik, seperti ketidakmampuan atau gangguan mental, keadaan fisik, emosi tidak seimbang, sikap merugikan dan kebiasaan yang salah.

2. Faktor eksternal, seperti keadaan sekolah, keadaan keluarga, dan lingkungan sekitarnya.

Guru mempunyai kontrol atas banyak faktor yang berpengaruh secara signifikan terhadap prestasi dan perilaku peserta didik. Sekolah dan guru yang bekerja sama dengan populasi peserta didik yang sama akan berbeda dalam 
kemampuan meraka untuk membantu peserta didik mengembangkan perilaku yang diharapkan dan meningkatkan prestasi siswa. Mortimore (1987) menyimpulkan penelitian mereka pada faktor yang mempengaruhi akademik peserta didik dan pencapaian sosial.(Jones, Vern, 2012, hlm. 10)

Dalam pengukuran tentang kemajuan membaca, ditemukan bahwa sekolah sekitar enam kali lebih penting dari pada latar belakang (faktor usia, jenis kelamin, kelas sosial, dan ras). Matematika dan menulis, perbedaanya sepuluh kali lipat. Analisis kemampuan berbicara dan sosial juga menunjukkan pentingnya peran sekolah... yang penting disini adalah kebijakan dan proses kontrol dilakukan kepala sekolah dan guru. Faktor-faktor ini dapat diubah dan diperbaiki.(Jones, Vern, 2012, hlm. 10)

Melihat beberapa contoh permasalahan yang diatas maka perlu adanya kegiatan analisis awal terhadap kemampuan belajar dari peserta didik itu sendiri, sehingga data terkait kemampuan belajar, karakter dan latar belakang peserta didik dapat diketahui, selain itusaat ini peserta didik membutuhkan model pembelajaran yang menarik, menyenangkan dan epektif, sehingga guru harus mampu menyajikan sebuah materi dengan model pembelajaran yang tepat sesuai kondisi peserta didik.

\section{Solusi yang Diberikan Oleh Guru Dalam Menyelesaikan Permasalahan Belajar Peserta Didik.}

Sebelum membahas beberapa poin penting terkait dengan solusi yang akan diberikan kepada peserta didik dalam proses pemenuhan kebutuhan belajar peserta didik ditengah pandemi covid-19, secara singkat akan digambarkan beberapa poin penting yang harus dikuasai oleh guru menghadapi karakteristik pendidikan diabad ke-21 saat ini yang dikenal sebagai empat pilar pendidikan, yaitu;

\section{Learning to know.}

Pilar pertama pendidikan learning to know (belajar untuk mengetahui atau belajar untuk berfikir). Proses learning ini sangat penting, karena berkaitan dengan cara/alat dan tujuan dari eksistensi manusia. Dikatakan sebagai cara/alat, karena manusia melaluinya bisa mempelajari dan memahami dunia sekitarnya, sedikitnys berupa pengetahuan pokok yang harus dimiliki sebagai modal 
menjalani hidup bermartabat, mengerti bagaimana cara mengembangkan skill khususnya, serta memiliki kemampuan berkomunikasi dengan orang lain.(Musfah, 2015, hlm. 168)

\section{Learning to Do}

Learning to Do atau dikenal sebagai proses berbuat dan bekerja sangat berhubungan dengan occupational training(training kejujuran). Pertanyaan yang akan ditimbulkan, bagaimana cara guru masa kini mengadaptasi pendidikankan yang mampu menyiapkan peserta didik yang memiliki kemampuan melakukan pekerjaan dimasa yang akan datang.(Musfah, 2015, hlm. 170) Learning to Do tidak hanya boleh diartikan sebagai proses menyiapkan orang secara professional dibidang khusus, akan tetapi learnig to do bisa diartikan sebagai suatu upaya dari certified skill to personal competence (kemampuan yang tersetifikasi menjadi kecakapan personal). Learning to do menyiapkan peserta didik berkemampuan yang mampu melakukan inovasi konsep.(Musfah, 2015, hlm. 170)

\section{Learning to Live Together}

Learning to live together merupakan pelajaran tentang hidup bersama orang yang memiliki latar belakang yang berbeda seperti suku, etnis, ras dan agama serta keyakinan. Oleh karena para ahli merekomendasikan pendidikan untuk mencapai target dalam learning to live together dengan mengambil dua pendekatan berikut. Pertama, sejak peserta didik berada pada masa kanak-kanak dibuat program pendidikan yang selalu berhubungan dan berinteraksi dengan orang banyak yang memiliki perbedaan seperti suku, agama, etnis, dan keyakinan. Kedua, dibuat program pendidikan yang membuat peserta didik terlibat dalam banyak kegiatan bersama yang melibatkan orang banyak. Program pembelajaran ini diorientasikan pada towards common goal.Ini adalah salah satu cara efektif untuk menghindarkan konflik atau untuk memecahkan masalah laten soal konflik.(Musfah, 2015, hlm. 170-171)

\section{Learning to Be}

Soal "belajar" menjadi (diri sendiri) ini berkaitan dengan satu prinsip Fundamental, yaitu bahwa pendidikan bertujuan mengembangkan kemampuan 
setiap orang, baik dari segi fikiran (mind) atau fisik (body), kecerdasan (intelligence), sensivitas, kemampuan menghargai seni dan spiritualitas. Semua peserta didik harus mendapatkan pada usia anak-anak dan remajanya suatu pendidikan yang membantu mereka untuk mengembangkan kebebasan yang dimilikinya, cara berfikir kritikal yang benar dan keputusan untuk memilih dan menjadi ahli apa dalam kehidupannya. Dengan learning to be peserta didik mampu mencari jalan keluar atas berbagai persoalan yang dihadapinya, mampu membuat keputusan dan sanggup mengemban tugas dan tanggung jawab.(Musfah, 2015, hlm. 171)

Untuk mengatasi kesulitan belajar peserta didik ada dua pendekatan yang dapat digunakan. Pertama, mencegah kesulitan belajar agar tidak menular kepada yang lainnya. Kedua, menyembuhkan peserta didik yang sedang mengalami kesulitan belajar. Upaya penyembuhan kesulitan belajar peserta didik akan lebih mudah apabila dibantu dengan alat-alat tertentu, seperti observasi, angket, wawancara, meneliti hasil pekerjaan anak, tugas kelompok, penggunaan buku rapor, home visit dan sebagainya.

Berikut beberapa solusi yang dapat digunakan menyelesaikan persoalan peserta didik baik dalam konteks pribadi maupun proses pembelajaran yang diberikan ditengah pandemi covid-19 ini:

\section{Memotivasi belajar peserta didik}

Menurut Corno dan Rhorkemper, mereka mengemukakan empat tugas penting yang yang dilakukan oleh guru dalam memotivasi peserta didik, yaitu:(Rivai, Veitzhal, 2012, hlm. 723)

1. Mengatur tugas-tugas termasuk pekerjaan rumah.

2. Membuat tugas-tugas yang sesuai.

3. Membuat atau memelihara motivasi sepanjang tahun.

4. Membangun atau mengubah kapasitas murid dalam mengevaluasi diri.

Abraham Maslow meyakini bahwa ketidakpuasan kebutuhan individu adalah sumber motivasi utama. Ia menempatkan lima kebutuhan dalam bentuk hierarki dari yang paling mendasar hingga yang paling matang, yakni kebutuhan dasar fisik untuk survival, keamanan, rasa memiliki, status ego, dan aktualisasi 
diri.(Rivai, Veitzhal, 2012, hlm. 725) Karena pada dasarnya setiap orang selalu memiliki dorongan yang kuat untuk maju, ingin menjadi lebih baik dari orang lain.

Eccles dan Wigfield (1985) mengatakan bahwa motivasi dapat dibagi kedalam 3 jenis nilai, yaitu:

1. Nilai instrik, minat sederhana atau kesenangan yang berkaitan dengan keterlibatan dalam suatu tugas.

2. Nilai pencapaian, nilai pencapaian prestasi, kemasyhuran, atau pengaruh melalui penyelesaian tugas.

3. Nilai kebergunaan, manfaat untuk karier seseorang atau tujuan personal yang diasosiasikan dengan keberhasilan melaksanakan tugas.

Guru perlu memastikan ada paling tidak satu nilai jika ingin para peserta didik termotivasi oleh tugas.(Jones, Vern, 2012, hlm. 240)

Dalam kegiatan belajar, motivasi dapat dikatakan sebagai keseluruhan daya penggerak didalam diri siswa yang menimbulkan kegiatan belajar, motivasi dapat dikatakan sebagai keseluruhan daya penggerak didalam diri peserta didik yang menimbulkan kegiatan belajar, menjamin kelangsungan dari kegiatan belajar dan yang memberikan arah pada kegiatan belajar, sehingga tujuan yang dikendaki oleh subjek belajar dapat tercapai.(Sardiman, 2014, hlm. 75)

\section{Pendekatan guru secara pribadi}

Dalam proses pembelajaran dikelas, tantangannya kemudian sangat banyak, hal ini bisa saja diakibatkan oleh karakter peserta didik yang berbeda-beda. Dalam satu rombongan belajar dikelas, tidak semua peserta didik mampu memahami materi dengan cepat, dan kemungkinan yang belum mampu memahami dengan baik itu terdapat beberapa orang.

Terjadinya perselisihan antara siswa yang masih belum mampu memikirkan tindakannya dengan baik. Antara satu siswa dengan siswa lain sering bermasalah. Tugas guru kemudian adalah mencari cara bagaimana agar permasalahan tersebut dapat diselesaikan dengan tepat dan cepat.

Bagi peserta didik yang sering mengalami masalah dengan teman sekelas atau masalah dengan pelajaran, didekati secara individual lalu memberikan 
nasehat-nasehat yang baik yang dapat diterima oleh peserta didik, lalu memberikan contoh-contoh sebab akibat yang akan terjadi ketika peserta didik tersebut tidak mau memperbaiki tingkah lakunya.

Pendekatan guru seperti ini adalah satu strategi belajar model Humanistic Education, adalah upaya-upaya untuk membantu peserta didik agar dapat mencapai perwujudan dirinya (self realization) sesuai dengan kemampuan dasar dan keunikan yang dimiliki. Cara pendekatannya masih bersifat enquiry discovery based approaches.Karakteristik pendekatan ini antara lain, bahwa guru jangan membuat jarak terlalu jauh dengan peserta didik. Ia harus menempatkan diri berdampingan dengan peserta didik sebagai peserta didik senior yang selalu siap menjadi sumber konsultan.(Rianto, 2009, hlm. 140)

Perlu adanya pemahaman atas kebutuhan personal peserta didik, identitas dan kebanggaan adalah kriteria sukses. Individu tanpa identitas seperti tanaman tanpa air. Usaha yang tulus untuk mengapresiasi makna menjadi warga Negara kelas bawah dalam masyarakat yang berorientasi kelas menengah, dan memahami tekanan psikologis yang ada karena situasi ini akan membantu anda memahami bahwa kelompok yang berbeda akan merasakan situasi dengan cara yang berbeda. Serta hubungan antara peserta didik dan guru yang positif, karena anak membutuhkan seseorang yang yang dapat memahami mereka sesuai level mereka dan menciptakan hubungan yang personal. Anak lebih membutuhkan model daripada kritik.(Jones, Vern, 2012, hlm. 19)

Sebagai tugas guru yang akan mengajar peserta didik, para guru harus mampu mengetahui teori-teori, hakikat mengajar, serta dapat melaksanakan tugas dan kewajibanyya dengan baik. Menurut Nasution, beberapa prinsip yang berlaku untuk guru yang baik, yaitu:(Kiat Sukses Menjadi Guru Yang Menyenangkan | Diones Aliaski Blog, t.t.)

1. Guru memahami serta menghormati peserta didik.

2. Guru harus menguasai bahan pelajaran, mengetahui cara menggunakannya dan kegunaannya bagi peserta didik.

3. Guru mampu menyesuaikan antara metode mengajar dan materi atau bahan pelajaran yang digunakan. 
4. Guru mampu menyesuaikan materi pelajaran dengan tingkat kemampuan peserta didik.

5. Guru harus mengaktifkan peserta didik dalam proses pembelajaran.

6. Guru mengaitkan antara pelajaran dengan kebutuhan peserta didik.

7. Merumuskan tujuan pelajaran yang hendak dicapai pada saat pelajaran berlangsung.

8. Kreatifitas guru tidak boleh hanya terarah ada teks dibuku saja.

Tugas fungsi dan tanggung jawab guru sangatlah besar khususnya dalam proses mengajar, membina dan mendidik peserta didik menjadi manusia-manusia yang baik dan berbudi pekerti, sehingga menjadi catatan kecil dalam penelitian ini kesejahteraan guru-guru perlu diperhatikan oleh para pemegang kendali kebijakan. Oleh karena itu guru tidak boleh melepaskan diri dari proses pembelajaran untuk memenuhi kebutuhan belajar peserta didik ditengah pandemi covid-19 yang saat ini memberikan pengaruh besar kepada kelancara pendidikan saat ini khususya di Indoesia.

Strategi Pembelajaran yang digunakan oleh guru dalam memenuhi kebutuhan belajar peserta didik ditengah pandemi covid-19.

\section{Pembelajaran online}

Ditengah pandemi covid-19 salah satu cara yang digunakan oleh pihak sekolah SD negeri 66 Gantarang khususnya kelas 6 adalah pembelajaran online, pihak sekolah menyiapkan fasilitas berupa tablet belajar untuk peserta didik kelas 6. Dalam pembelajaran online ini para guru fokus kepada kelas 6 dengan pertimbangan kelas 6 sudah mampu diajak belajar secara daring, adapun akses yang digunakan yaitu dengan sistem pembelajaran melalui aplikasi group WA dan messenger gratis yang tersedia pada aplikasi disetiap tablet yang dibagikan kepada peserta didik. Sehingga peserta didik tidak perlu mengadakan tatap muka didalam kelas, semua proses pembelajaran dilakukan oleh guru dari jarak jauh sehingga proses pemenuhan kebutuhan belajar peserta didik tetap terlaksana dengan baik, dari pihak wali kelas mengontrol penuh kegiatan belajar tersebut.

Menurut Agus, selaku wali kelas 6, pembelajaran untuk kelas 6 harus lebih diutamakan, sehingga tablet yang disediakan oleh sekolah kami gunakan untuk 
kelas 6 saja dulu, tidak lama lagi mereka akan ujian nasional, jadi supaya kegiatan pembelajaran ini berjalan mudah kami gunakan sistem belajar online, jadi semua siswa kelas 6 diberikan tablet belajar, sehingga tidak ada lagi peserta didik yang mengeluh tidak punya handphone android yang bisa digunakan, apalagi anak kelas 6 hanya satu dua orang yang punya handphone. Pihak sekolah memfasilitasi mereka sehingga kebutuhan belajar peserta didik dapat dapat dimaksimalkan pemenuhannya.

Salah satu cara yang umum digunakan adalah pembelajaran dengan sistem online, akan tetapi sistem pembelajaran online banyak dikeluhkan oleh para orang tua peserta, karena anak-anak SD kelas 6 pada umumya belum memiliki alat komunikasi pribadi, langkah sekolah dengan menghadirkan alat bantu berupa tablet android sangat membantu peserta didik, khusunya kelas 6 yang waktu belajarnya perlu diberikan perhatian ekstra.

\section{Pembelajaran tatap muka dari rumah kerumah}

Dalam proses pembelajaran tatap muka dari rumah kerumah ini dilakukan khusus untuk kelas 5 kebawah, para guru atau wali kelas akan mendatangi setiap rumah peserta didik untuk memberikan buku materi pelajaran kepada peserta didik, memberikan tugas yang akan dikerjakan, dan pengumpulannya dilakukan dengan cara yang sama yaitu para guru mendatangi rumah peserta didik yang menjadi anak walinya. Sehingga tidak ada kelas khusus disekolah, akan tetapi kelas belajarnya dirumah dan setiap jam pelajaran para guru akan keliling untuk mengontrol kegiatan belajar peserta didiknya.

Selanjutnya para guru akan melakukan hal yang sama ketika waktu yang diberikan kepada peserta didik telah selesai maka guru akan mendatangi rumah peserta didik kembali untuk memberikan tugas atau materi yang akan dipelajari peserta didik minggu kedua dan seterusnya. Cara ini dirasa cukup epektif dilakukan oleh para guru ditengah pandemi ini, kebutuhan belajar peserta didik tetap terpenuhi ditengah pandemi covid-19 dan tetap mematuhi protokoler kesehatan yang berlaku. Kebutuhan belajar peserta didik menjadi terpenuhi, aktifitas libur sekolah diganti dengan pembelajaran dirumah, namun materi-materi pelajaran peserta didik tetap berjalan dengan baik. 
Menurut Rahma, proses pembelajaran harus dilakukan agar peserta didik tidak terlepas dari kegiatan belajar, apalagi anak-anak domisilinya disekitar desa Gantarang saja, sehingga mudah untuk diakses, palingan kendalanya cuman cuaca saja, karena saat ini musim hujan jadi kadang butuh waktu agak lama untuk bisa kerumah peserta didik semuanya.(Rahma, 2020)

Model pembelajaran ini menurut hemat penulis salah satu aternatif yang dapat digunakan oleh guru dalam proses pendidikan saat ini ditengah maraknya keluh kesah para orang tua peserta didik aka sulitnya mengajar anak-anak mereka dirumah, mahalnya biaya yang harus dikeluarkan ketika harus belajar online. Dengan guru mendatangi rumah setiap peserta didik maka guru dan orang tua dapat bekerja sama dalam mengawasi peserta didik dalam pelajaran yang diberikan.

\section{Pembelajaran jarak jauh dengan kerja sama antara guru dan orang tua peserta didik.}

Dalam kegiatan pembelajaran jarak jauh yag dilakukan guru bertujuan untuk membantu peserta didik agar lebih mudah memahami materi pelajaran yang diberikan. Pembelajaran jarak jauh ini merupakan lanjutan dari pembelajaran tatap muka dari rumah kerumah peserta didik. Agar proses pelajaran berjalan maksimal, para guru bekerja sama dengan guru dalam mengawasi aktifitas belajar peserta didik.

Para guru membuat group WA dengan para orang tua peserta didik yang memahami cara penggunaan group WA, akan tetapi tidak semua orang tua peserta didik memiliki group WA, sehingga guru memberikan nomor telfon mereka, agar ketika peserta didik mengalami hambatan belajar yang berkaitan dengan materi atau tugas yang diberikan, maka orang tua peserta didik akan menelfon guru lalu menjelaskan tentang persoalan yang dihadapi peserta didik dalam belajar atau menyelesaikan tugas yang diberikan, sehingga proses pembelajaran tetap berjalan dengan baik dengan kontrol dari guru yang bekerja sama dengan orang tua peserta didik.

Menurut Nurlia selaku wali kelas 3, metode kerja sama ini dilakukan agar peserta didik yang rumahnya agak jauh bisa dengan mudah diberi tahu jika ada 
informasi, atau jika ada tugas yang tidak dipahami, orang tua peserta didik tinggal menelfon guru kelasnya untuk menanyakan tugas tersebut, jadi tidak perlu lagi datang disekolah atau dirumah untuk urusan itu.(Nurlia, 2020)

Dengan adanya strategi pembelajaran yang digunakan oleh para guru sangat membantu proses pembelajaran itu sendiri, sehingga proses pendidikan tidak terhenti ditengah pademi covid-19. Hal ini menjadi suatu tuntutan profesional kerja yang dilakukan oleh para guru menghadapi persoalan pendidikan saat ini.

\section{KESIMPULAN}

Guru tidak boleh berpangku tangan mengadapi persoalan kesulitan belajar ditengah pandemi covid-19 yang terjadi saat ini atau merasa sulit dengan adanya sistem pembelajaran dirumah, sebagai guru yang memiliki tanggung jawab penuh harus mampu memberikan solusi teraik, guru harus selalu berupaya untuk memenuhi kebutuhan belajar peserta didik. Adapun hak-hak peserta didik sesuai dengan pasal 12 adalah sebagai berikut (1) Mendapatkan pendidikan agama sesuai dengan agama yang dianutnya dan diajarkan oleh pendidik yang seagama. (2) Mendapatkan pelayanan pendidikan sesuai dengan bakat, minat dan kemampuannya. (3) Mendapatkan beapeserta didik bagi yang berprestasi yang orang tuanya tidak mampu membiayai pendidikan. (4) Mendapatkan biaya pendidikan bagi mereka yang orang tuanya tidak mampu membiayai pendidikannya. Pindah keprogram pendidikan pada jalur dan satuan pendidikan lain yang setara. Menyelesaikan program pendidikan sesuai dengan kecepatan belajar masing-masing dan tidak menyimpang dari ketentuan batas waktu yang diterapkan. (5) Dalam melaksanakan tanggung jawabnya sebagai tenaga pendidik, guru memiliki tanggung jawab yang besar untuk memenuhi kebutuhan peserta didik, sehingga guru memiliki tanggung jawab yang begitu besar terhadap terpenuhinya kebutuhan dari peserta didik itu sendiri. Ditengah pandemi covid-19 para guru di SD Negeri 66 Gantarang berupaya memaksimalkan proses pembelajaran dengan menggunakan beberapa strategi pembelajaran seperti penerapan belajar online untuk kelas 6 dengan sekolah memberikan fasilitas 
berupa tablet belajar berbasis android untuk peserta didik, pembelajaran tatap muka dari rumah kerumah peserta didik untuk kelas bawah dan proses pembelajaran jarak jauh dengan kerjasama antara guru dan orang tua peserta didik guna memaksimalkan proses pembelajaran dirumah ditengah pandemi covid-19 saat ini. 


\section{DAFTAR PUSTAKA}

Arifin, Z. (2013). Evaluasi Pembelajaran Prinsip, Teknik, Prosedur. PT Remaja Rosdakarya.

Bagaimana Pembelajaran yang Sesuai Kebutuhan Siswa. (t.t.). Diambil 6 Maret 2021, dari http://novehasanah.blogspot.com/2017/09/pembelajaran-sesuaikebutuhan-siswa.html

Djunaidi, M, and M. J. (2012). Metodologi Penelitian Kualitatif. Ar-Ruzz Meida. Hsubky, B. (2014). Identifikasi Kebutuhan Siswa Dan Tehnik Pembelajaran. journal of islamic education, 7 No 2, 17.

Jones, Vern, and L. J. (2012). Komprehensif, Manajemen Kelas. Kencana.

Kiat Sukses Menjadi Guru Yang Menyenangkan | Diones Aliaski Blog. (t.t.). $\begin{array}{llll}\text { Diambil } & 6 & \text { Maret } & \text { 2021, }\end{array}$ https://dionesaliaski.wordpress.com/pendidikan/islami/kiat-suksesmenjadi-guru-yang-menyenangkan/

Musfah, J. (2015). Redesain Pendidikan Guru Teori, Kebijakan dan Praktik. Prenadamedia Group.

Nata, A. (2003). Manajemen Pendidikan: Mengatasi Kelemahan Pendidikan Islam Di Indonesia. Kencana.

Nurdin, Syafruddin, and A. (2016). Kurikulum Dan Pembelajaran. Rajawali Pers. Nurlia. (2020). Hasil Wawancara.

Pendidikan yang Menggugah dan Menggairahkan di Tengah Covid-19. (t.t.). $\begin{array}{lllll}\text { Diambil } & 6 & \text { Maret } & \text { 2021, }\end{array}$ https://edukasi.kompas.com/read/2020/05/02/120848771/pendidikanyang-menggugah-dan-menggairahkan-di-tengah-covid-19 
Rahma. (2020). Hasil Wawancara.

Rianto, Y. (2009). Paradigma Baru Pembelajaran Sebagai Referensi Baru Bagi Guru/Pendidik Dalam Implementasi Pembelajaran Yang Efektif Dan Berkualitas. Prenadamedia Group.

Rivai, Veitzhal, and S. M. (2012). Education Management: Analisis Teori Dan Praktek. Rajawali Pers.

Rohani, Ahmad, and A. Ahmadi. (1995). Pengolaan Pengajaran. Rineka Cipta.

Sanjaya, W. (2006). Strategi Pembelajaran Berorientasi Standar Proses Pendidikan. Prenadamedia Group.

Sardiman. (2014). Interaksi Dan Motivasi Belajar Mengajar. Rajawali Pers.

Susanto, A. (2013). Teori Belajar Dan Di Sekolah Dasar. Prenadamedia Group.

Syah, R. H. (2020). Dampak Covid-19 pada Pendidikan di Indonesia: Sekolah, Keterampilan, dan Proses Pembelajaran. SALAM: Jurnal Sosial dan Budaya Syar-i, 7(5). https://doi.org/10.15408/sjsbs.v7i5.15314

Wena, M. (2008). Pembelajaran Inovatif Kontemporer. Bumi Aksara.

Wiyani, N. A. (2013). Desain Pembelajaran Pendidikan. Ar-Ruzz Media.

Yaumi, M. (2013). Prinsip-Prinsip Desain Pembelajaran: Disesuaikan Dengan Kurikulum 2013. Kencana. 